Jurnal Akuntansi dan Bisnis: Jurnal Program studi Akuntansi, 5 (1) Mei 2018.

ISSN 2443-3071 (Print) ISSN 2503-0337 (Online). DOI: 10.31289/iab.v5i1.2321

JURNAL AKUNTANSI DAN BISNIS

Jurnal Program Studi Akuntansi

Available online http://ojs.uma.ac.id/index.php/jurnalakundanbisnis

\title{
ANALISA RASIO KEUANGAN TERHADAP RETURN ON ASSET PADA SUBSEKTOR BANK YANG TERDAFTAR DI BEI
}

\author{
Frima Lumban Gaol ${ }^{a}$, Windi Astria Trinanda ${ }^{a}$, Putri Aprilia ${ }^{a}$, Ckristina Meilinda \\ Simanjuntak ${ }^{a}$
}

${ }^{a}$ Fakultas Ekonomi dan Bisnis, Universitas Prima Indonesia

Diterima Maret 2019; Disetujui April 2019; Dipublikasikan Mei 2019

\begin{abstract}
Abstrak
Penelitian ini bertujuan untuk menguji Capital Adequacy Ratio (CAR), BOPO dan Loan to Deposit Ratio (LDR) secara parsial dan simultan terhadap Return On Asset (ROA) pada perusahaan perbankan yang terdaftar di Bursa Efek Indonesia Periode 2012-2017. Sampel penelitian ini diperoleh 28 perusahaan yang terseleksi menggunakan purposive sampling dengan kriteria tertentu. Jenis data yang digunakan dalam penelitian ini adalah data kuantitatif. Sumber data dalam penelitian ini adalah data sekunder. Teknik pengumpulan data dalam penelitian ini adalah model analisis berganda (linear), uji asumsi klasik dan uji hipotesis dalam menganalisis data penelitian. Hasil penelitian secara parsial menunjukkan bahwa Capital Adequacy Ratio (CAR) dan Loan to Deposit Ratio (LDR) berpengaruh positif dan signifikan sedangkan BOPO berpengaruh negatif tidak signifikan terhadap Return On Asset (ROA) pada perusahaan perbankan yang terdaftar di Bursa Efek Indonesia. Secara simultan Capital Adequacy Ratio (CAR), BOPO dan Loan to Deposit Ratio (LDR) berpengaruh signifikan terhadap Return On Asset (ROA) pada perusahaan perbankan yang terdaftar di Bursa Efek Indonesia.
\end{abstract}

Kata Kunci : Capital Adequacy Ratio (CAR), BOPO, Loan to Deposit Ratio (LDR), Return On Asset (ROA)

\begin{abstract}
This study aims to examine the Capital Adequacy Ratio (CAR), BOPO and Loan to Deposit Ratio (LDR) partially and simultaneously to Return On Assets (ROA) in banking companies listed on the Indonesia Stock Exchange for the 2012-2017 period. The research sample was obtained by 28 selected companies using purposive sampling with certain criteria. The type of data used in this study is quantitative data. The data source in this study is secondary data. Data collection techniques in this study are multiple analysis models (linear), classic assumption tests and hypothesis testing in analyzing research data. the results of the research partially show that the Capital Adequacy Ratio (CAR) and Loan to Deposit Ratio (LDR) have a positive and significant effect while the BOPO has a negative but not significant effect on Return On Assets (ROA) on banking companies listed on the Indonesia Stock Exchange. Simultaneously the Capital Adequacy Ratio (CAR), BOPO and Loan to Deposit Ratio (LDR) have a significant effect on Return On Assets (ROA) in banking companies listed on the Indonesia Stock Exchange.
\end{abstract}

Keyword: Capital Adequacy Ratio (CAR), BOPO, Loan to Deposit Ratio (LDR), Return On Asset (ROA)

How To Cite: Gaol, F.L. et, al. (2019). Analisa Rasio Keuangan Terhadap Return On Asset Pada Subsektor Bank Yang Terdaftar di BEI. Jurnal Akuntansi dan Bisnis: Jurnal Program Studi Akuntansi, 5 (1): 53-59

* email: frimalumbangaol41@gmail.com

\section{PENDAHULUAN}

Bank merupakan salah satu perusahaan yang mempunyai peran penting dalam mendorong pertumbuhan perekonomian suatu negara (Rauf, A. 2018). Bank dianggap 
sebagai suatu lembaga keuangan yang aman dalam melakukan berbagai macam aktivitas keuangan, lembaga yang berfungsi sebagai perantara keuangan antara pihak-pihak yang mempunyai dana dengan pihak-pihak yang memerlukan dana dan bank juga berfungsi sebagai lembaga keuangan yang memperlancar aliran lalu lintas pembayaran. Bank juga sebagai suatu industri yang dalam kegiatan usahanya mengandalkan kepercayaan masyarakat sehingga mestinya tingkat kesehatan bank perlu di perhatikan (Alanshari, F., \& Marlius, D. 2018).

Return On Asset (ROA) memfokuskan kemampuan perusahaan-perusahaan untuk memperoleh keuntungan dalam kegiatan operasi perusahaan dengan memanfaatkan aktiva yang dimilikinya dalam menghasilkan keuntungan. Perusahaan yang bertujuan mencari laba akan berusaha mendapatkan laba yang optimal dan menigkatkan pelayanan kepada masyarakat (Nazir, N., \& Agustina, N. 2019). Capital Adequacy Ratio (CAR) ataupun kecukupan modal menjadi titik tumpuan utama dalam mendirikan suatu perusahaan. Modal yang besar akan mendukung kegiatan operasional perusahaan, begitu pula dengan bank. Bank yang tidak memiliki modal yang tinggi tidak akan mampu melindungi perusahaan dari risiko yang akan timbul dalam menjalankan kegiatan usahanya. Sehingga bank tersebut tidak memiliki sumber daya financial yang cukup untuk berjaga-jaga terhadap potensi kerugian. Untuk mengukur tingkat ketercukupan modal maka digunakan rasio Capital Adequacy Ratio (CAR), semakin baik rasio kecukupan modal berdampak pada meningkatnya nilai ROA bank tersebut (Indrawati, N., Wardiningsih, S. S., \& Wibowo, E. 2018)

Perolehan laba sangat ditentukan oleh pendapatan yang diperoleh dari biaya operasional yang harus di keluarkan untuk memperoleh pendapatan tersebut. Terjadinya kenaikan laba suatu bank disebabkan oleh efisiensi bank dalam mengendalikan operasionalnya. Efisiensi operasional merupakan masalah kompleks dimana setiap perusahaan sub sektor bank selalu berusaha untuk beroperasi dengan efisien (Setiono, B. A. 2018).

Faktor lain yang dapat mempengaruhi laba suatu bank adalah Loan to Deposit Ratio (LDR) ataupun penyaluran kredit (Darwis, M., Widarko, A., \& Salim, M. A. 2018). Penyaluran kredit merupakan kegiatan utama bank. Tetapi kemampuan bank dalam memberikan kredit atau menyalurkan dana kepada masyarakat tentunya harus seimbang dengan banyaknya simpanan yang diperoleh bank. Apabila simpanan yang diperoleh dari nasabah terlalu besar, sementara bank kurang bisa menyalurkan dalam bentuk pinjaman , maka bank tidak bisa memanfaatkan uang simpanan tersebut untuk menhasilkan laba. Oleh karena itu diperlukan keseimbangan antara simpanan yang diterima dan pinjaman yang diberikan oleh bank yang tercermin pada Loan to Deposit Ratio (LDR) yang menggambarkan kemampuan suatu bank dalam mengendalikan simpanan dan pinjaman sehingga dapat meningkatkan nilai ROA bank tersebut.

Penelitian ini ingin melihat apakah pengaruh Capital Adequacy Ratio (CAR) terhadap Return On Asset (ROA) pada sub sektor bank yang terdaftar di Bursa Efek Indonesia periode tahun 2012-2017, juga bagaimana pengaruh BOPO terhadap Return On Asset (ROA) pada sub sektor bank yang terdaftar di Bursa Efek Indonesia dan pengaruh Loan to Deposit Ratio (LDR) terhadap Return On Asset (ROA) pada sub sektor bank yang terdaftar di Bursa Efek Indonesia

Capital Adequacy Ratio (CAR) merupakan bagaimana sebuah perbankan mampu membiayai aktivitas kegiatannya dengan kepemilikan modal yang dimilikinya (Fahmi, 2014:181). Keberhasilan suatu bank bukan terletak pada jumlah modal yang dimilikinya, tetapi lebih didasarkan kepada bagaimana bank mempergunakan modal itu untuk menarik sebanyak mungkin dana/simpanan masyarakat yang kemudian disalurkan 
kepada masyarakat yang membutuhkan sehingga membentuk pendapatan bagi bank (Pandia, 2012;28). Capital Adequacy Ratio berguna untuk mengukur kemampuan dana intern menutup kredit macet. Semakin besar nilai rasio ini semakin baik performa perkreditan cabang tersebut karena makin besar dana yang tersedia untuk menutup kredit macet (Rivai et, al., 2013:306). Menurut Dendawijaya, (2009:121) Capital Adequacy Ratio (CAR) dapat dihitung dengan menggunakan rumus:

$$
C A R=\frac{\text { Modal Bank }}{\text { Aktiva Tertimbang }} \times 100 \%
$$

BOPO merupakan rasio yang digunakan untuk mengukur kemampuan manajemen bank dalam mengendalikan biaya operasional terhadap pendapatan operasional (Pandia, 2012:72). Pendapatan operasional digunakan untuk menampung semua hasil langsung dari kegiatan usaha bank. Sedangkan beban operasional merupakan semua beban yang dikeluarkan dalam rangka kegiatan yang lazim dilakukan sebagai usaha bank (Taswan, 2012:32-33). Operating ratio yang tinggi adalah tidak menguntungkan karena berarti proporsi laba usaha akan rendah yang mungkin tidak cukup untuk menutup beban bunga, dividen dan beban lainnya (Jumingan, 2014:164). Dengan demikian menurut Harmono (2011) BOPO dapat dihitung dengan menggunakan rumus:

$$
B O P O=\frac{\text { Biaya operasional }}{\begin{array}{c}
\text { Pendapatan } \\
\text { Operasonal }
\end{array}} \times 100 \%
$$

Loan to Deposit Ratio (LDR) merupakan rasio yang digunakan untuk mengukur komposisi jumlah kredit yang diberikan dibandingkan dengan jumlah dana masyarakat dan modal sendiri yang digunakan (Kasmir, 2012:225). Tujuan dalam perhitungan LDR merupakan untuk mengetahui serta menilai sampai berapa jauh bank memiliki kondisi sehat dalam menjalankan operasi atau kegiatan usahanya atau dengan kata lain, sebagai suatu indikator untuk mengetahui tingkat kerawanan suatu bank (Wardiah, 2013:298). Semakin tinggi rasio tersebut memberikan indikasi semakin rendahnya kemampuan likuiditas bank yang bersangkutan. Hal ini disebabkan karena jumlah dana yang di perlukan untuk membiayai kredit menjadi semakin besar (Dendawijaya, 2009: 116). Menurut Pandia (2012) Loan to Deposit Ratio (LDR) dapat dihitung dengan menggunakan rumus:

$$
L D R=\frac{\text { Kredit }}{\text { Dana Pihak Ketiga }} X 100 \%
$$

Return on asset merupakan rasio yang menunjukkan hasil (return) atas penggunaan asset perusahaan dalam menciptakan laba bersih. Dengan kata lain, rasio ini digunakan untuk mengukur seberapa besar jumlah laba bersih yang akan dihasilkan dari setiap rupiah dana yang tertanam dalam total asset (Hery, 2017:144). ROA berfungsi mengukur efektivitas perusahaan dalam menghasilkan laba dengan memanfaatkan aktiva yang dimiliki. Semakin besar ROA yang dimiliki oleh sebuah perusahaan, semakin efisien penggunaan aktiva sehingga akan memperbesar laba. Laba yang besar akan menarik investor karena perusahaan memiliki tingkat kembalian yang semakin tinggi (Wardiah, 2013:299). Dengan demikian menurut Wira (2011) Return On Asset (ROA) dapat dihitung dengan menggunakan rumus:

$$
R O A=\frac{\text { Net Income }}{\text { Total Assets }}
$$




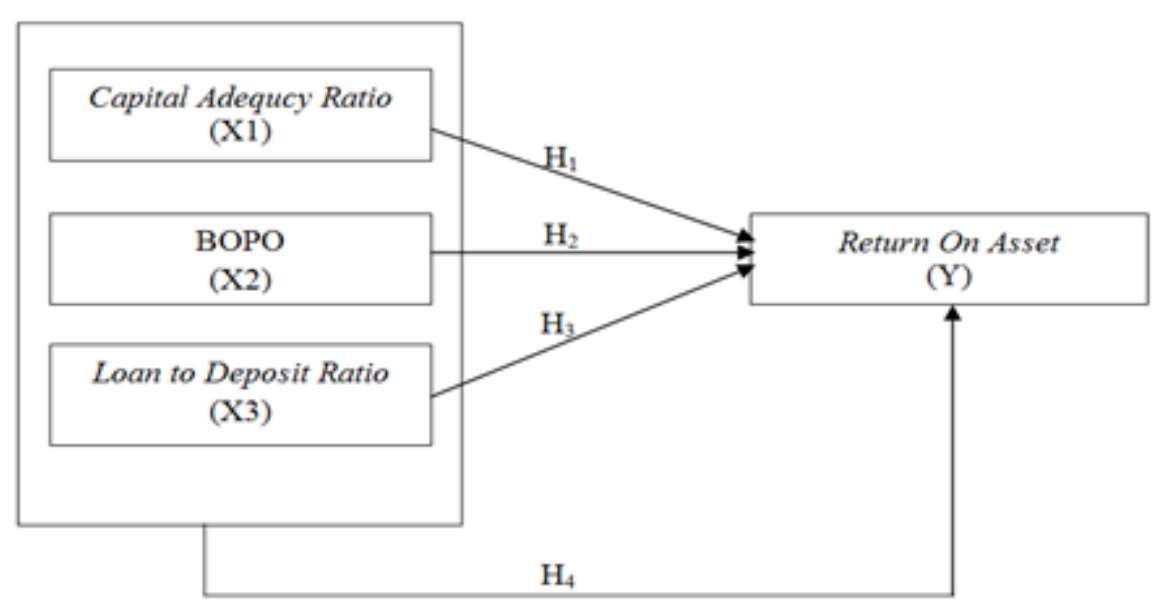

Gambar 1.1 Kerangka konsep

Hipotesis adalah suatu pernyataan yang pada waktu diungkapkan belum diketahui kebenarannya, maka hipotesis dalam penelitian ini adalah: Capital Adequacy Ratio (CAR), BOPO, dan Loan to Deposit Ratio (LDR) berpengaruh secara parsial terhadap Return On Asset (ROA) pada perusahaan sub sektor bank yang terdaftar di Bursa Efek Indonesia pada periode tahun 2012-2017. Capital Adequacy Ratio (CAR), BOPO, dan Loan to Deposit Ratio (LDR) berpengaruh secara simultan terhadap Return On Asset (ROA) pada perusahaan sub sektor bank yang terdaftar di Bursa Efek Indonesia.

\section{METODE PENELITIAN}

Jenis penelitian ini adalah penelitian kausal. Populasi dalam penelitian ini adalah semua perusahaan sub sektor bank yang terdaftar di Bursa Efek Indonesia pada periode tahun 2012-2017 yang berjumlah 43 Perusahaan. Teknik pengambilan sampel dengan cara Purposif Sampling maka di peroleh 28 perusahaaan sampel dengan 168 unit analisis observasi selama 6 tahun.

\section{HASIL DAN PEMBAHASAN}

\section{Uji normalitas}

Tabel 1.1 Uji Normalitas Kolmogorov-Sminov

\begin{tabular}{ccr}
\hline & & $\begin{array}{r}\text { Unstandardized } \\
\text { Residual }\end{array}$ \\
\hline N & Mean & 168 \\
Normal Parametersa,b & Std. Deviation & $0 \mathrm{E}-7$ \\
& Absolute & .72130463 \\
Most Extreme Differences & Positive & .069 \\
& Negative & .040 \\
Kolmogorov-Smirnov Z & -.069 \\
Asymp. Sig. (2-tailed) & .901 \\
& .392 \\
\hline a. Test distribution is Normal. & \\
b. Calculated from data. &
\end{tabular}


Berdasarkan hasil di atas, dapat diketahui bahwa nilai kolmogorov-smirnovZ 0,901 di atas 0,05, hal ini mengidentifikasi bahwa data berdistribusi normal.

\section{Uji Multikolonearitas}

\begin{tabular}{|c|c|c|}
\hline \multirow[t]{2}{*}{ Model } & \multicolumn{2}{|c|}{ Collinearity Statistics } \\
\hline & Tolerance & VIF \\
\hline (Constant) & & \\
\hline LN_CAR & .268 & 3.729 \\
\hline LN_BOPO & .826 & 1.211 \\
\hline LN_LDR & .274 & 3.654 \\
\hline
\end{tabular}

Dari hasil perhitungan uji tersebut diatas maka diperoleh nilai VIF $<10$ dan nilai tolerance $>0,1$ dan hal itu menunjukkan bahwa tidak terdapat gejala multikolineritas.

\section{Uji Autokorelasi}

Tabel 1.3 Uji Autokorelasi

\begin{tabular}{|c|c|c|c|c|}
\hline Model & $\mathrm{R}$ & Adjusted R Square & $\begin{array}{l}\text { Std. Error of the } \\
\text { Estimate }\end{array}$ & Durbin-Watson \\
\hline 1 & $.361^{\mathrm{a}}$ & 130 & .72787 & 1.225 \\
\hline
\end{tabular}

Berdasarkan tabel 1.3 hasil uji Durbin Watson menunjukkan sebesar 1,225 angka DW tersebut diantara -2 sampai +2 sehingga dapat disimpilkan tidak terjadi autokorelasi.

\section{Analisis Regresi Linear}

Tabel 1.4 Hasil Persamaan Regresi Linear Berganda

\begin{tabular}{crrr}
\hline Model & \multicolumn{2}{c}{ Unstandardized Coefficients } & \multicolumn{2}{c}{$\begin{array}{c}\text { Standardized } \\
\text { Coefficients } \\
\text { Beta }\end{array}$} \\
\hline (Constant) & -4.246 & Std. Error & .404 \\
LN_CAR & -.452 & .096 & -.661 \\
LN_BOPO & -.053 & .074 & -.057 \\
LN_LDR & .304 & .077 & .554 \\
\hline
\end{tabular}

Berdasarkan Tabel III.4 pada kolom Unstandardized Coefficients bagian B diperoleh model permasaan regresi linear berganda yaitu: Return On Asset $=-4,246-0,452$ LN_CAR - 0,053 LN_BOPO + 0,304 LN_LDR. Untuk hasil interprestasi dari regresi tersebut dapat di ketahui bahwa nilai konstanta (a) $=-4,246$ menunjukkan apabila nilai variabel bebas yaitu Capital Adequacy Ratio, BOPO, Loan to Deposit Ratio bernilai konstan, maka nilai Return On Asset menurun sebesar 4,246. Koefisien regresi Capital Adequacy Ratio sebesar -0,452 menyatakan bahwa setiap kenaikan sebesar 1 satuan Capital Adequacy Ratio, maka akan menyebabkan penurunan Return On Asset sebesar 0,452 dengan asumsi variabel lain dianggap nol. Koefisien regresi BOPO sebesar -0,053 menyatakan bahwa setiap kenaikan sebesar 1 satuan BOPO, maka akan menyebabkan penurunan Return On Asset sebesar 0,053 dengan asumsi variabel lain dianggap nol. Koefisien regresi Loan to Deposit Ratio sebesar 0,304 menyatakan bahwa setiap kenaikan sebesar 1 satuan Loan to Deposit Ratio, maka akan menyebabkan kenaikan Return On Asset sebesar 0,452 dengan asumsi variabel lain dianggap nol. 


\section{Koefisien Determinasi}

Tabel 1.5 Uji Koefisien Determinasi

\begin{tabular}{|c|c|c|c|c|}
\hline Model & $\mathrm{R}$ & R Square & Adjusted R Square & $\begin{array}{l}\text { Std. Error of the } \\
\text { Estimate }\end{array}$ \\
\hline 1 & $.361^{a}$ & .130 & .114 & .72787 \\
\hline
\end{tabular}

Berdasarkan tabel III.5 uji koefisien determinasi menunjukkan besarnya udjested $R$ square sebesar 0,114 yang berarti 11,5\% Return On Asset dijelaskan oleh Capital Adequacy Ratio, BOPO, Loan to Deposit Ratio secara bersama-sama. Sisanya sebesar 88,6\% dijelaskan oleh variabel-variabel lain yang tidak diteliti dalam penelitian ini.

\section{Uji Simultan (F)}

Tabel 1.6 Hasil Uji F

\begin{tabular}{|c|c|c|c|c|c|c|}
\hline & Model & Sum of Squares & Df & Mean Square & $\mathrm{F}$ & Sig. \\
\hline \multirow[b]{2}{*}{1} & Regression & 13.014 & 3 & 4.338 & 8.188 & $.000^{\mathrm{b}}$ \\
\hline & Residual & 86.887 & 164 & .530 & & \\
\hline
\end{tabular}

a. Dependent Variable: LN_ROA

b. Predictors: (Constant), LN_LDR, LN_BOPO, LN_CAR

Dari tabel 1.6 diatas dapat dilihat hasil uji simultan (uji F) diperoleh $F_{\text {hitung sebesar }}$ 8,188 dengan dengan nilai signifikan 0,000 ,dfl (jumlah variabel -1$)=2$ dan df2 $(n-k)=$ 165 maka diperoleh $F_{\text {tabel }}$ sebesar 3,05. Sehingga dapat disimpulkan bahwa $F_{\text {hitung }}>F_{\text {tabel }}$ $(8,188>3,05)$ dengan nilai signifikan $0,000^{\mathrm{b}}$ dibawah nilai 0,05 maka $\mathrm{H}_{0}$ ditolak dan $\mathrm{H}_{\mathrm{a}}$ diterima, yang berarti efisiensi Capital Adequacy Ratio, BOPO, Loan to Deposit Ratio secara simultan berpengaruh signifikan terhadap Return On Asset pada perusahaan Sub Sektor Bank yang terdaftar di Bursa Efek Indonesia tahun 2012-2017.

\section{Uji Parsial T}

Tabel 1.7 Hasil Uji T

\begin{tabular}{|c|c|c|c|c|c|c|}
\hline & \multirow[t]{2}{*}{ Model } & \multicolumn{2}{|c|}{ Unstandardized Coefficients } & \multirow{2}{*}{$\begin{array}{c}\text { Standardized } \\
\text { Coefficients } \\
\text { Beta } \\
\end{array}$} & \multirow[t]{2}{*}{$\mathrm{t}$} & \multirow[t]{2}{*}{ Sig. } \\
\hline & & $\mathrm{B}$ & Std. Error & & & \\
\hline \multirow{4}{*}{1} & (Constant) & -4.246 & .404 & & -10.506 & .000 \\
\hline & LN_CAR & -.452 & .096 & -.661 & -4.702 & .000 \\
\hline & LN_BOPO & -.053 & .074 & -.057 & -.715 & .476 \\
\hline & LN_LDR & .304 & .077 & .554 & 3.979 & .000 \\
\hline
\end{tabular}

a. Dependent Variable: LN_ROA

Hasil pengujian statistik secara parsial dengan dfl $=3$ dan dfl2 (n-k) $=162$ menjelaskan bahwa variabel Capital Adequacy Ratio mempunyai nilai signifikan 0,000 < 0,05 selain itu hasil thitung $-4,702<t_{\text {tabel }} 1,65431$ maka $\mathrm{H}_{0}$ diterima dan $\mathrm{H}_{\mathrm{a}}$ ditolak dengan artinya Capital Adequacy Ratio berpengaruh negatif dan signifikan terhadap Return On Asset pada perusahaan Sub Sektor Bank yang terdaftar di Bursa Efek Indonesia tahun 2012-2017. variabel BOPO mempunyai nilai signifikan 0,476>0,05 selain itu hasil thitung - 
$0,715<t_{\text {tabel }} 1,65431$ maka $\mathrm{H}_{0}$ diterima dan $\mathrm{H}_{\mathrm{a}}$ ditolak dengan artinya BOPO berpengaruh negatif dan tidak signifikan terhadap Return On Asset pada perusahaan Sub Sektor Bank yang terdaftar di Bursa Efek Indonesia tahun 2012-2017. variabel Loan to Deposit Ratio mempunyai nilai signifikan $0,000<0,05$ selain itu hasil thitung 3,979 $>t_{\text {tabel }} 1,65431$ maka $\mathrm{H}_{0}$ ditolak dan $\mathrm{H}_{\mathrm{a}}$ diterima dengan artinya Loan to Deposit Ratio berpengaruh positif dan signifikan terhadap Return On Asset pada perusahaan Sub Sektor Bank yang terdaftar di Bursa Efek Indonesia tahun 2012-2017.

\section{SIMPULAN}

Berdasarkan hasil analisis dan uji hipotesis yang dihasilkan, dapat disimpulkan bahwa secara simultan Capital Adequacy Ratio, BOPO, Loan to Deposit Ratio secara simultan berpengaruh signifikan terhadap Return On Asset. Selanjutnya, secara parsial Capital Adequacy Ratio berpengaruh negatif dan signifikan terhadap Return On Asset, artinya BOPO berpengaruh negatif dan tidak signifikan terhadap Return On Asset, dan Loan to Deposit Ratio berpengaruh positif dan signifikan terhadap Return On Asset.

\section{DAFTAR PUSTAKA}

Alanshari, F., \& Marlius, D. (2018). Prosedur Pemberian Kredit KPR Pada PT. Bank Tabungan Negara (Persero) TBK Cabang Pembantu Bukittinggi.

Darwis, M., Widarko, A., \& Salim, M. A. (2018). Pengaruh Capital Adequacy Ratio (Car), Non Performing Loan (Npl), Loan To Deposit Ratio (Ldr), Suku Bunga Sbi Terhadap Kinerjakeuangan Perbankan (Pada Industri Perbankan Yang Go Public Di Bursa Efek Indonesia Periode Tahun 2014-2016). Jurnal Ilmiah Riset Manajemen, 7(03).

Dendawijaya lukman. (2009). Manajemen Perbankan. Jakarta: Ghalia Indonesia.

Fahmi Irham. (2014). Analisis Kinerja Keuangan. Bandung: Alfabeta.

Harmono. (2012). Manajemen Keuangan. Jakarta: Bumi Aksara.

Hery. (2017). Analisi Laporan Keuangan. Jakarta: PT Grasindo.

Indrawati, N., Wardiningsih, S. S., \& Wibowo, E. (2018). Pengaruh capital adequacy ratio, non perfoming financing, financing to deposit ratio, biaya operasional, dan pendapatan operasional, dan ukuran perusahaan terhadap return on asset bank umum syariah di indonesia. Jurnal Ekonomi dan Kewirausahaan, 18(2).

Jumingan. (2014). Analisis Laporan Keuangan. Jakarta: PT Bumi Aksara.

Kasmir. (2012). Manajemen Perbankan. Jakarta: Rajawali Pers.

Nazir, N., \& Agustina, N. (2019). Pengaruh Firm Size, DER, ROA dan Current Asset terhadap Price Value pada Perusahaan Manufaktur Sub Sektor Tekstil di Indonesia. Jurnal Visioner \& Strategis, 7(2).

Pandia Frianto. (2012). Manajemen Dana dan Kesehatan Bank. Yogyakarta: Rineka Cipta.

Rauf, A. (2018). Struktur kepemilikan, diversifikasi pendapatan, dan resiko bank di Indonesia (Doctoral dissertation, Widya Mandala Catholic University Surabaya).

Rivai Veithzal, dkk. 2013. Commercial Bank Management manajemen perbankan. Jakarta: PT Rajagrafindo Persada.

Setiono, B. A. (2018). Pengaruh Return on Asset (ROA) dan Return on Equity (ROE) Terhadap Capital Adequacy Ratio (CAR) Sektor Perbankan yang Terdaftar di Bursa Efek Indonesia. Jurnal Aplikasi Pelayaran dan Kepelabuhanan, 7(2), 117-129.

Taswan. 2010. Akutansi Perbankan. Yogyakarta: UPP STIM YKPN.

Wardiah Mia Lasmani. 2013. Dasar-Dasar Perbankan. Bandung: Pustaka Setia.

Wira Desmon. 2011. Analisis Fundamental Saham. Exceed. 